\title{
Apelin Receptor Early Endogenous Ligand
}

National Cancer Institute

\section{Source}

National Cancer Institute. Apelin Receptor Early Endogenous Ligand. NCI Thesaurus.

Code C137986.

Apelin receptor early endogenous ligand ( $54 \mathrm{aa}, \sim 7 \mathrm{kDa}$ ) is encoded by the human APELA gene. This protein plays a role in heart and cardiovascular system development. 